\title{
Standardization of a Nal(TI) scintillation detector and its use on environments for Geology teaching in a Brazilian university
}

\author{
Eder Queiroz Barbosa ${ }^{1}$. Daniel Marcos Bonotto ${ }^{1} \cdot$ Gabrielle Roveratti $^{1}$
}

Received: 3 August 2017 / Accepted: 29 January 2018 / Published online: 7 February 2018

(c) Springer-Verlag GmbH Germany, part of Springer Nature 2018

\begin{abstract}
This paper describes analytical protocols adopted for calibrating a portable gamma rays spectrometer using a $2^{\prime \prime} \times 2^{\prime \prime} \mathrm{NaI}(\mathrm{Tl})$ scintillation detector for performing exploration and environmental surveys. The steps involved the determination of counting times with good accuracy, calibration in energy and concentration, and data conversion to effective dose (Ed) for monitoring the radioactivity levels in the air, for indoor and outdoor environments. The $\chi^{2}$ test was applied to the counting rate data acquired for ten different readings, allowing determine the greater accuracy among them. Some standards yielded values above of the detection limit for calibrating the $\mathrm{K}$, eU, and $\mathrm{eTh}$ windows, whereas empirical equations provided satisfactory results. The count rates in these windows were obtained in selected environments related to Geology teaching activities in a Brazilian university. Then, they were converted to Ed, showing the applicability of the adopted procedures for environmental surveys. The radiological monitoring showed two sites exhibiting Ed values above the WHO guideline reference value of $1 \mathrm{mSv} / \mathrm{year}$. The first was in a minerals and rocks museum and the second in a deposit (litoteca) dedicated to the rocks storage. Thus, the members of the public are only occasionally exposed to the natural gamma radiation there. Additionally, the Ed values are much lower than the recommended limit of $20 \mathrm{mSv} / \mathrm{year}$ for occupationally exposed individuals.
\end{abstract}

Keywords Portable gamma rays spectrometer $\cdot \mathrm{NaI}(\mathrm{Tl})$ scintillation detector $\cdot$ Calibration $\cdot \mathrm{K}$, eU, and eTh windows $\cdot$ Effective dose

\section{Introduction}

Portable gamma rays spectrometry has been used since the 1960s for uranium exploration, geologic mapping, and environmental studies (Duval et al. 2005). The mapping of the natural radioelements $\mathrm{K}, \mathrm{U}$, and $\mathrm{Th}$ has been done based on windows centered over the energy photopeaks of $1461 \mathrm{keV}$ $\left({ }^{40} \mathrm{~K}\right), 1765 \mathrm{keV}\left({ }^{214} \mathrm{Bi}\right)$, and $2615 \mathrm{keV}\left({ }^{208} \mathrm{Tl}\right)$, respectively (IAEA 1989). Additionally, several methods to estimate the radionuclides concentration from the nuclear fallout have been developed. For instance, the ${ }^{137} \mathrm{Cs}$ and ${ }^{134} \mathrm{Cs}$ precipitation may be detected by monitoring two $\sim 100 \mathrm{keV}$ windows centered in the energies of $662 \mathrm{keV}$ and $796 \mathrm{keV}$, respectively (Grasty and Cox 1997). Thus, such methods typically use windows of different $\gamma$-rays energies emitted by each

Daniel Marcos Bonotto

danielbonotto@yahoo.com.br

1 Instituto de Geociências e Ciências Exatas-IGCE, Universidade Estadual Paulista-UNESP, Av. 24-A No. 1515, P.O. Box 178, Rio Claro, São Paulo CEP 13506-900, Brazil radionuclide, which are discriminated in equipment like multichannel analyzer (MCA) (IAEA 2003).

The field procedures for portable spectrometry depend on the research purpose, generally prospecting or environmental. The spectrometer type, detector volume, counting time, and measurement mode depend on the environmental radiation, which is linked to the type, size, and radioactive sources distribution. For such purpose, scintillation $\mathrm{NaI}(\mathrm{Tl})$ crystals of up to $350 \mathrm{~cm}^{3}$ have been extensively used as $\gamma$-rays detectors over the last 45 years (Adams and Freyer 1964; Adams and Gasparini 1970; Sudarshan et al. 1992; Leo 1994; Perez-Andujar and Pibida 2004; Knoll 2010; L'Annunziata 2012; Acton 2013).

Differential spectrometers are among the recent $\gamma$-rays equipment, for instance, $350 \mathrm{~cm}^{3} \mathrm{NaI}(\mathrm{Tl})$ detectors that record data between 1024 and 2048 channels (energy range 0-3 MeV) (Acton 2013). The automatic spectrum stabilization occurs by the use of a reference radionuclide like ${ }^{137} \mathrm{Cs}$, ${ }^{40} \mathrm{~K}$, or ${ }^{208} \mathrm{Tl}$ whose respective $\gamma$-rays energy photopeak corresponds to 662,1461 , and $2615 \mathrm{keV}$. The instruments can save the whole spectrum and select channels over a broad 
energy window in order to estimate the in situ concentration of the natural radioelements $\mathrm{K}, \mathrm{U}$, and Th (L'Annunziata 2012; Acton 2013). The calibration constants are stored in the equipment's memory that is able to record thousands of field measurements or hundreds of total spectra. Acceptable precision for quantitative analysis may be acquired from the use of large volume scintillation crystals or by increasing the counting time (L'Annunziata 2012; Acton 2013).

$\mathrm{NaI}(\mathrm{Tl})$ detectors $\left(\right.$ density $=3.66 \mathrm{~g} / \mathrm{cm}^{3}$ ) have been largely applied to determine the formations density, chemical composition, soil salinity, and mineralogy as exhibit efficient detection, great robustness, reduced humidity sensitivity, and enhanced capacity to deal with higher counting rates without pulse pilling. Additionally, scintillator crystals of higher density like CsI $\left(4.51 \mathrm{~g} / \mathrm{cm}^{3}\right), \mathrm{LaBr}_{3}\left(5.29 \mathrm{~g} / \mathrm{cm}^{3}\right)$, and $\mathrm{Bi}_{4} \mathrm{Ge}_{3} \mathrm{O}_{12}$ (BGO-bismuth germinate; $7.13 \mathrm{~g} / \mathrm{cm}^{3}$ ) have been also used in order to improve the detection efficiency for the higher $\gamma$-rays energies (L’Annunziata 2012; Acton 2013).

It is important to highlight that smaller detectors permit a weight reduction to about $2 \mathrm{~kg}$ (Stoller et al. 1994). Also, BGO crystals $\left(103 \mathrm{~cm}^{3}\right)$ exhibit $~ 80 \%$ sensitivity of a $\mathrm{NaI}(\mathrm{Tl})$ detector $\left(350 \mathrm{~cm}^{3}\right)$ (Saint-Gobain 2016). NaI(Tl) crystals should be clean for applications involving low background counts and not contain $\mathrm{K}$ levels above $0.5 \mathrm{ppm}$ in the whole mass. In contrast, the BGO detector may have a primary ${ }^{207} \mathrm{Bi}$ contamination due to four $\gamma$-rays emissions from 470 to $2400 \mathrm{keV}$ (Saint-Gobain 2016).

The response of a portable $\gamma$-rays spectrometer is dependent of the size, location, and geometry of the radioactive sources. Significant measures along one crossing can only be obtained if the source-detector geometry is constant to all observations. The detector must be also placed directly onto the ground surface, or it should be kept in a low but constant height for minimizing the effects of local reliefs' variation and radioelements distribution (Kogan et al. 1971; IAEA 1989). In order to obtain reliable measurements, the same source-detector geometry used to calibrate the spectrometer must be adopted in the field.

The counting time of each field measurement depends on the source radioactivity and requested precision. The $\mathrm{K}, \mathrm{U}$, and Th readings may be complicated due to the photopeaks overlap in the gamma spectra (Lфvborg and Mose 1987). In general, there is a commitment between the count rate precision and the minimum counting time required during the field reading. For example, counting times of 2 and $6 \mathrm{~min}$ are reasonable for highly and low radioactive rocks, respectively, when using a $350 \mathrm{~cm}^{3} \mathrm{NaI}(\mathrm{Tl})$ detector (L $\phi$ vborg and Mose 1987).

Concrete pads of variable sizes possessing different concentration of natural radioelements are sometimes used for calibrating the $\gamma$-rays spectrometers. However, their access difficulty or high cost for most users justifies the adoption of more simple customized procedures as described in this paper. It is considered here a portable $\gamma$-rays spectrometer based on a traditional $\mathrm{NaI}(\mathrm{Tl})$ scintillation detector and several standards of easy acquisition or preparation in the laboratory. The developed analytical protocols allow surveys interesting to Economic Geology (geochemical/geophysical prospecting of radioactive ores like U-deposits) and Environmental/Medical Geology (evaluation of health risk due to the radiation exposure). A study case has been also illustrated here considering typical environments available in schools and universities dedicated to producing geologists and/or other Earth scientists.

\section{Experimental steps}

A digiDART high-performance portable digital MCA $\gamma$-rays spectrometer using a $2^{\prime \prime} \times 2^{\prime \prime}\left(103 \mathrm{~cm}^{3}\right) \mathrm{NaI}(\mathrm{Tl})$ scintillation detector model 2BY2-DD from ORTEC-AMETEK has been used for $\gamma$-rays spectrometry in this study. The detector probe weight is $\sim 4.6 \mathrm{~kg}$, whose power consumption is $240 \mathrm{~mW}$. It includes a preamplifier, a high-voltage power supply, and a cable for coupling to digiDART-LF. Such unit contains an amplifier, a 2048 MCA controlled by MAESTRO software and a LCD monitor, allowing visualize and store the acquired spectra.

This $\gamma$-rays spectrometer was initially calibrated for energy readings on using artificial and natural radioactive sources: ${ }^{137} \mathrm{Cs},{ }^{60} \mathrm{Co}$, a solution containing ${ }^{133} \mathrm{Ba}$, pure powdered $\mathrm{KCl}(52 \mathrm{wt} \%$ in $\mathrm{K})$ as a ${ }^{40} \mathrm{~K}$ source, pitchblende standard $(1 \% \mathrm{U})$ as a ${ }^{214} \mathrm{Bi}$ source, and monazite sand standard $(1 \% \mathrm{Th})$ as a ${ }^{208} \mathrm{Tl}$ source. Then, for applicability in mineral deposits exploration and environmental surveys, it was calibrated for concentration readings on utilizing standards possessing variable contents of the natural radioelements $\mathrm{K}$, $\mathrm{U}$, and Th. Altogether 19 standards were inserted in $2.3-\mathrm{cm}-$ high and $6.3-\mathrm{cm}$-diameter aluminum cans, whose radioactivity levels were taken inside a lead shielding for avoiding contribution of lateral radiation reaching the detector. The shielding consisted of two 4-cm-high, 14.5-cm-external diameter and 8.5 -cm-internal diameter rings that yielded a 6-cm-thick protective lead wall.

Pitchblende and monazite sand standards having different uranium and thorium concentrations (NBL-101-A, NBL102-A, NBL-103-A, NBL-104-A, NBL-105-A, NBL-106-A, NBL-107-A, NBL-108-A, NBL-109-A, and NBL-110-A) and providing from New Brunswick Laboratory, US Department of Energy, Argonne, Illinois, USA, were submitted to $\gamma$-rays readings after waiting ${ }^{222} \mathrm{Rn}$ to reach secular radioactive equilibrium with ${ }^{226} \mathrm{Ra}$ (at least 25 days). Such condition occurs when the number of parent atoms disintegrating per unit time equals to that of the daughter atoms formed at the same time. It happens when the parent half-life is much higher (at least 7 times) than that of the daughter 
radionuclide (Ivanovich and Harmon 1992). In the ${ }^{238} \mathrm{U}$ decay series, such time is $\sim 4$ weeks for the ${ }^{226} \mathrm{Ra}^{222} \mathrm{Rn}$ pair.

Three well-homogenized samples of stream sediments (LII-Th-1, LII-Th-2, and LII-Th-3) from Morro do Ferro, Poços de Caldas plateau were also used for yielding lower Th concentrations. Pure $\mathrm{KCl}$ ( $52 \mathrm{wt} \%$ in $\mathrm{K}$, standard LII$\mathrm{KCl}-1)$ and different mixtures prepared from this matrix and additions of pure $\mathrm{SiO}_{2}$ were utilized to obtain variable potassium concentration. The standard K6 (LII-KCl-6) consisted of $99.99 \%$ purity $\mathrm{SiO}_{2}$ for providing the background radioactivity level. More details of the standards composition and concentration are given in Table 1.

Saving time is very important and practical mainly on field surveys like those using the gamma rays analysis. Thus, the "optimum counting time" would correspond to the minimum counting time required for assuring the precision of the radiometric measurement within an acceptable analytical uncertainty. Such parameter may be obtained by evaluating the changes in the number of counts, counting time, or counting rate. In this paper, it was done taking into account 380 readings for the Th (160), K (120), and U (100) standards. Ten counting times were adopted for the standards and background readings: $30,60,90,120,180,240,300,600$, 900 , and $1800 \mathrm{~s}$.

The count rate sometimes is low during the gamma spectrometric readings. To determine whether the observed signal is "true" or "false," the critical level of detection $\left(L_{\mathrm{c}}\right)$ (Currie 1968) may be adopted. It is expressed in Eq. 1, where $N_{\mathrm{B}}$ is the number of background counts and $t$ is the counting time. If $t$ is in min, then $L_{\mathrm{c}}$ is given in cpm (count rate). Currie (1968) also defined the detection limit ( $L_{\mathrm{D}}$, also in cpm, if $t$ is in min) according to Eq. 2, whose evaluation must be done when the net counts in a spectral region are lower than $L_{\mathrm{c}}$. In this paper, a large database of background readings performed with standard $\mathrm{K} 6$ (pure $\mathrm{SiO}_{2}$ ) for $\mathrm{K}$, eU, and eTh windows allowed determine the mean $L_{\mathrm{c}}$ and $L_{\mathrm{D}}$ values.

$L_{\mathrm{c}}=\frac{N_{\mathrm{B}}+\left(2.33 \times \sqrt{N_{\mathrm{B}}}\right)}{t}$

$L_{\mathrm{D}}=\frac{N_{\mathrm{B}}+\left(2.71+4.65 \times \sqrt{N_{\mathrm{B}}}\right)}{t}$

\section{Results and discussion}

\section{Calibration in energy}

Table 2 reports the channels identified in the gamma spectra recorded in the MCA and the corresponding energy peaks. Such data allowed generate the energy calibration curve of the portable gamma spectrometer (Fig. 1), expressed by the following relationship:

$E=1.647 C h-8.3605$

where $E$ is the energy (in $\mathrm{keV}$ ) and $C h$ is the channel number in the MCA. This curve is useful, among other purposes, for avoiding false photopeaks identification in the
Table 1 Description of the standards used for calibrating the portable $\gamma$-rays spectrometer in this study

\begin{tabular}{lllll}
\hline Standard & Code & Composition & Weight $(\mathrm{g})$ & Concentration \\
\hline $\mathrm{K} 1$ & LII-KCL-1 & $61.5 \mathrm{~g} \mathrm{KCl}$ & 61.50 & $52 \%$ \\
$\mathrm{~K} 2$ & LII-KCL-2 & $54.16 \mathrm{~g} \mathrm{SiO}_{2}+28.9 \mathrm{~g} \mathrm{KCl}$ & 83.06 & $25 \%$ \\
$\mathrm{~K} 3$ & LII-KCL-3 & $80.12 \mathrm{~g} \mathrm{SiO}_{2}+5.80 \mathrm{~g} \mathrm{KCl}$ & 85.92 & $5 \%$ \\
$\mathrm{~K} 4$ & LII-KCL-4 & $82.11 \mathrm{~g} \mathrm{SiO}_{2}+2.90 \mathrm{~g} \mathrm{KCl}$ & 85.01 & $2.5 \%$ \\
$\mathrm{~K} 5$ & LII-KCL-5 & $84.72 \mathrm{~g} \mathrm{SiO}_{2}+0.5 \mathrm{~g} \mathrm{KCl}$ & 85.22 & $0.5 \%$ \\
$\mathrm{~K} 6$ & LII-KCL-6 & $50 \mathrm{~g} \mathrm{SiO}_{2}$ & 50 & $0 \%$ \\
$\mathrm{U} 1$ & NBL-101-A & Pitchblende $+\mathrm{SiO}_{2}$ & 50 & $10,070 \mathrm{ppm}$ \\
$\mathrm{U} 2$ & NBL-102-A & Pitchblende $+\mathrm{SiO}_{2}$ & 50 & $1025 \mathrm{ppm}$ \\
$\mathrm{U} 3$ & NBL-103-A & Pitchblende $+\mathrm{SiO}_{2}$ & 50 & $499 \mathrm{ppm}$ \\
$\mathrm{U} 4$ & NBL-104-A & Pitchblende $+\mathrm{SiO}_{2}$ & 48.96 & $98.8 \mathrm{ppm}$ \\
$\mathrm{U} 5$ & NBL-105-A & Pitchblende $+\mathrm{SiO}_{2}$ & 50 & $10.2 \mathrm{ppm}$ \\
Th1 & NBL-106-A & Monazite sand $+\mathrm{SiO}_{2}$ & 50 & $10,290 \mathrm{ppm} \mathrm{Th}+400 \mathrm{ppm} \mathrm{U}$ \\
Th2 & NBL-107-A & Monazite sand $+\mathrm{SiO}_{2}$ & 50 & $1028 \mathrm{ppm} \mathrm{Th}+40 \mathrm{ppm} \mathrm{U}$ \\
Th3 & NBL-108-A & Monazite sand $+\mathrm{SiO}_{2}$ & 50 & $515 \mathrm{ppm} \mathrm{Th}+20 \mathrm{ppm} \mathrm{U}$ \\
Th4 & NBL-109-A & Monazite sand $+\mathrm{SiO}_{2}$ & 48.96 & $105.2 \mathrm{ppm} \mathrm{Th}+4 \mathrm{ppm} \mathrm{U}$ \\
Th5 & NBL-110-A & Monazite sand $+\mathrm{SiO}_{2}$ & 50 & $10.4 \mathrm{ppm} \mathrm{Th}+0.4 \mathrm{ppm} \mathrm{U}$ \\
Th6 & LII-Th-1 & Stream sediments & 50 & $5 \mathrm{ppm} \mathrm{Th}$ \\
Th7 & LII-Th-2 & Stream sediments & 50 & $2.5 \mathrm{ppm} \mathrm{Th}$ \\
Th8 & LII-Th-3 & Stream sediments & 50 & $1.25 \mathrm{ppm} \mathrm{Th}$ \\
\hline
\end{tabular}


Table 2 Calibration of the $\gamma$-rays spectrometric system

\begin{tabular}{lrll}
\hline Radionuclide & Channel & Energy $(\mathrm{MeV})$ & Half-life \\
\hline${ }^{133} \mathrm{Ba}$ & 225 & 0.36 & 10.51 years \\
${ }^{214} \mathrm{Bi}$ & 1060 & 1.76 & 19.9 min \\
${ }^{40} \mathrm{~K}$ & 886 & 1.46 & $1.28 \times 10^{9}$ years \\
${ }^{60} \mathrm{Co}$ & 717 & 1.17 & 5.271 years \\
${ }^{60} \mathrm{Co}$ & 812 & 1.33 & 5.271 years \\
${ }^{60} \mathrm{Co}{ }^{1}$ & 1562 & 2.51 & 5.271 years \\
${ }^{137} \mathrm{Cs}$ & 411 & 0.66 & 30.07 years \\
${ }^{208} \mathrm{Tl}$ & 1571 & 2.61 & $183 \mathrm{~s}$ \\
\hline
\end{tabular}

Amplifier gains: coarse-1; fine-0.45. High voltage: 760-866 V. Energy and half-life values according to Chu et al. (1999)

${ }^{1}$ Summation photopeak

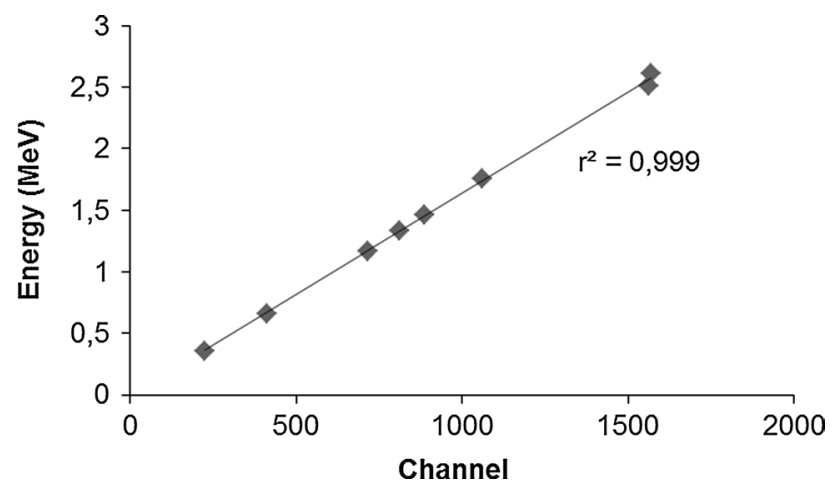

Fig. 1 Calibration of the portable gamma spectrometer for $\gamma$-rays energy readings

gamma spectra as sometimes verified in $\mathrm{NaI}(\mathrm{Tl})$ readings of the $\gamma$-rays associated with ${ }^{40} \mathrm{~K}(1.46 \mathrm{MeV})$ and ${ }^{214} \mathrm{Bi}$ (1.76 MeV).

The detector resolution was $6.3 \%$ in the $0.66 \mathrm{MeV}{ }^{137} \mathrm{Cs}$ photopeak that is within the range of 6.0-7.5\% as reported elsewhere (Adams and Gasparini 1970; L $\varphi$ vborg et al. 1976; Dickson and Scott 1997). However, the resolution improved according to the increased $\gamma$-rays energy, reaching $3.95 \%$ in the 2.61 $\mathrm{MeV}^{208} \mathrm{Tl}$ photopeak.

Table 3 shows the $\gamma$-rays energy windows adopted in this paper for radiometric monitoring of uranium (eU, equivalent uranium), thorium (eTh, equivalent thorium), and potassium aimed for geological prospecting and environmental surveys. They include a significant fraction of the total absorption photopeak area, thus, avoiding the interference of other neighbor photopeaks (L $\varphi$ vborg et al. 1976). The total counts window comprised a large energy interval of the gamma rays emitted by the natural radionuclides.

\section{Optimum counting time and detection limit}

The acquired number of counts data in the windows reported in Table 3 by MAESTRO software was inserted in Excel spreadsheet and used for calculating the net counting rate (in $\mathrm{cpm}$ ) after discounting the respective background values.

The average and variance values of the 10 readings were determined and used for application of the $\chi^{2}$ statistical test in order to verify if the counting rates obey the Poisson distribution (Young 1962; Bevington 1969; Davis 1986; Vuolo 1996). The estimated $\chi^{2}$ values were rejected when the probability was equal or lower than the pre-established limit ( $\alpha$ significance level $=0.025$ ) for belonging to the $\chi^{2}$ distribution with $N-1(N=10)$ freedom degrees (FD).

The $\chi^{2}$ reference values varied between $2.70>\chi^{2}>19.02$ $(t \geq 30 \mathrm{~s}, \mathrm{FD}=9)$ and $0.00>\chi^{2}>5.02(t \geq 900 \mathrm{~s}, \mathrm{FD}=1)$. The calculated $\chi^{2}$ values within the range of the expected ones indicated data obeying the Poisson distribution. Table 4 reports the optimum counting times found for the standards used in this paper.

Some unsatisfactory $\chi^{2}$ values were possibly related to background fluctuations in the laboratory as a consequence of $\gamma$-rays emissions associated with the indoor ${ }^{222} \mathrm{Rn}$ activity concentration. Additional equivalent field tests should be also realized as the described experiments were held under controlled lab conditions, not considering the larger surface area and volume of the exposed rocks, which certainly would imply on enhanced radioactivity levels due to the $\gamma$-rays emissions.

The mean $L_{\mathrm{c}}$ and $L_{\mathrm{D}}$ values are reported in Table 5. Their plots for $\mathrm{K}$, eU, and eTh against the counting time in Fig. 2 indicate systematic decreasing trends according to the following equations:

$$
\begin{aligned}
& L_{\mathrm{c}} \text { and } L_{\mathrm{D}}(\mathrm{K})=56.071 \times t^{-0.075}\left(r^{2}=0.847\right) \\
& L_{\mathrm{c}} \text { and } L_{\mathrm{D}}(\mathrm{eU})=24.471 \times t^{-0.109}\left(r^{2}=0.888\right)
\end{aligned}
$$

Table 3 Spectral windows adopted in this paper for evaluating uranium (eU), thorium (eTh), and potassium

\begin{tabular}{lllc}
\hline Window & Energy range $(\mathrm{MeV})$ & $\begin{array}{l}\text { Radionuclide and monitored } \\
\text { gamma emission }(\mathrm{MeV})\end{array}$ & Channel interval \\
\hline Total counts & $0.40-2.81$ & - & $240-1594$ \\
Potassium (K) & $1.37-1.57$ & ${ }^{40} \mathrm{~K}(1.46)$ & $796-886$ \\
Uranium (eU) & $1.66-1.86$ & ${ }^{214} \mathrm{Bi}(1.76)$ & $960-1070$ \\
Thorium (eTh) & $2.41-2.81$ & ${ }^{208} \mathrm{Tl}(2.62)$ & $1464-1594$ \\
\hline
\end{tabular}

Energy range and monitored radionuclides according to IAEA (1991) 
Table 4 Minimum counting time (optimum counting time) in the standards used in this paper required for assuring the precision of the $\gamma$-rays readings within the significance level of 0.025 an 9 freedom degrees
Table 5 Mean $L_{\mathrm{c}}$ and $L_{\mathrm{D}}$ values for $\mathrm{K}, \mathrm{eU}$, and $\mathrm{eTh}$ windows determined from Eqs. 1 and 2 according to different counting times

\begin{tabular}{|c|c|c|c|c|c|}
\hline \multirow[t]{2}{*}{ Standard } & \multirow[t]{2}{*}{ Weight $(\mathrm{g})$} & & \multicolumn{3}{|c|}{ Optimum counting time (s) } \\
\hline & & & $\mathrm{K}-40$ & Bi-214 & $\mathrm{Tl}-208$ \\
\hline & $\mathrm{KCl}$ & ${ }^{40} \mathrm{~K}$ & & & \\
\hline K6 & 0 & 0 & - & - & - \\
\hline K5 & 0.26 & $1.02 \times 10^{-4}$ & - & - & - \\
\hline K4 & 1.51 & $3.06 \times 10^{-4}$ & $\geq 600$ & - & - \\
\hline K3 & 3.02 & $5.16 \times 10^{-4}$ & $\geq 300$ & - & - \\
\hline K2 & 15.03 & $2.49 \times 10^{-3}$ & $\geq 90$ & - & - \\
\hline \multirow[t]{2}{*}{ K1 } & 31.98 & $3.84 \times 10^{-3}$ & $\geq 30$ & - & - \\
\hline & Pitchblende & ${ }^{238} \mathrm{U}$ & & & \\
\hline U5 & 50 & $5.06 \times 10^{-4}$ & - & - & - \\
\hline $\mathrm{U} 4$ & 50 & $4.90 \times 10^{-3}$ & $\geq 300$ & $\geq 600$ & - \\
\hline U3 & 50 & $2.48 \times 10^{-2}$ & $\geq 30$ & $\geq 600$ & $\geq 600$ \\
\hline $\mathrm{U} 2$ & 50 & $5.09 \times 10^{-2}$ & $\geq 30$ & $\geq 60$ & $\geq 600$ \\
\hline \multirow[t]{2}{*}{ U1 } & 50 & $5.00 \times 10^{-1}$ & $\geq 30$ & $\geq 60$ & $\geq 60$ \\
\hline & Monazite sand & ${ }^{232} \mathrm{Th}$ & & & \\
\hline Th8 & 50 & $6.25 \times 10^{-5}$ & - & - & - \\
\hline Th7 & 50 & $1.25 \times 10^{-4}$ & - & - & - \\
\hline \multirow[t]{2}{*}{ Th6 } & 50 & $2.50 \times 10^{-4}$ & - & - & - \\
\hline & Monazite sand & ${ }^{232} \mathrm{Th}-{ }^{238} \mathrm{U}$ & & & \\
\hline Th5 & 50 & $5.20 \times 10^{-4}-1.99 \times 10^{-5}$ & - & - & - \\
\hline Th4 & 50 & $5.26 \times 10^{-3}-1.99 \times 10^{-4}$ & - & $\geq 240$ & - \\
\hline Th3 & 50 & $2.58 \times 10^{-2}-9.93 \times 10^{-4}$ & $\geq 240$ & $\geq 120$ & $\geq 30$ \\
\hline Th2 & 50 & $5.14 \times 10^{-2}-1.99 \times 10^{-3}$ & $\geq 90$ & $\geq 30$ & $\geq 30$ \\
\hline Th1 & 50 & $5.15 \times 10^{-1}-1.99 \times 10^{-2}$ & $\geq 30$ & $\geq 30$ & $\geq 30$ \\
\hline
\end{tabular}

\begin{tabular}{llllllll}
\hline$t(\min )$ & \multicolumn{2}{l}{$L_{c}(\mathrm{cpm})$} & & & \multicolumn{2}{l}{$L_{D}(\mathrm{cpm})$} & \\
\cline { 2 - 3 } & $\mathrm{K}$ & $\mathrm{eU}$ & $\mathrm{eTh}$ & & $\mathrm{K}$ & $\mathrm{eU}$ & $\mathrm{eTh}$ \\
\hline 30 & 45.05 & 17.97 & 9.87 & & 47.84 & 19.74 & 11.18 \\
15 & 46.18 & 18.15 & 10.24 & & 50.18 & 20.66 & 12.13 \\
10 & 47.49 & 19.11 & 10.41 & & 52.47 & 22.27 & 12.76 \\
5 & 48.58 & 19.92 & 11.50 & & 55.71 & 24.50 & 15.01 \\
4 & 50.35 & 20.57 & 12.73 & & 58.46 & 25.78 & 16.85 \\
3 & 51.69 & 21.29 & 12.72 & & 61.20 & 27.43 & 17.51 \\
2 & 50.85 & 21.16 & 13.41 & 62.41 & 28.69 & 19.46 \\
1.5 & 51.24 & 23.78 & 14.17 & 64.68 & 33.04 & 21.40 \\
1 & 56.04 & 23.64 & 15.63 & & 73.20 & 34.94 & 24.98 \\
0.5 & 64.18 & 29.12 & 17.70 & 90.30 & 47.17 & 32.15 \\
\hline
\end{tabular}

$L_{\mathrm{c}}$ and $L_{\mathrm{D}}(\mathrm{eTh})=15.284 \times t^{-0.148}\left(r^{2}=0.961\right)$

\section{Calibration in concentration}

Grasty and Darnley (1971) suggested the stripping correction technique for converting the counting rates obtained in the $\mathrm{K}$, eU, and eTh windows into concentrations, without interference among them. The stripping factors $\alpha, \beta$, and $\gamma$ take into account the Compton effects in the $\gamma$-rays spectra, considering the counting rate in a lower energy window relatively to the higher one: $\alpha=\alpha_{\mathrm{U}, \mathrm{Th}} / \alpha_{\mathrm{Th}, \mathrm{Th}} ; \beta=\alpha_{\mathrm{K}, \mathrm{Th}} / \alpha_{\mathrm{Th}, \mathrm{Th}}$; $\gamma=\alpha_{\mathrm{K}, \mathrm{U}} / \alpha_{\mathrm{U}, \mathrm{U}}$. Contrarily, the reverse stripping factors $a$, $b$, and $g$ take into account the counting rate in a higher energy window relatively to the lower one: $a=\alpha_{\mathrm{Th}, \mathrm{U}} / \alpha_{\mathrm{U}, \mathrm{U}}$; $b=\alpha_{\mathrm{Th}, \mathrm{K}} / \alpha_{\mathrm{K}, \mathrm{K}} ; g=\alpha_{\mathrm{U}, \mathrm{K}} / \alpha_{\mathrm{K}, \mathrm{K}}$. In addition to Compton effects, sensitivity $(S)$ constants must be also taken into account, which are dependent of the detector size/efficiency/ 

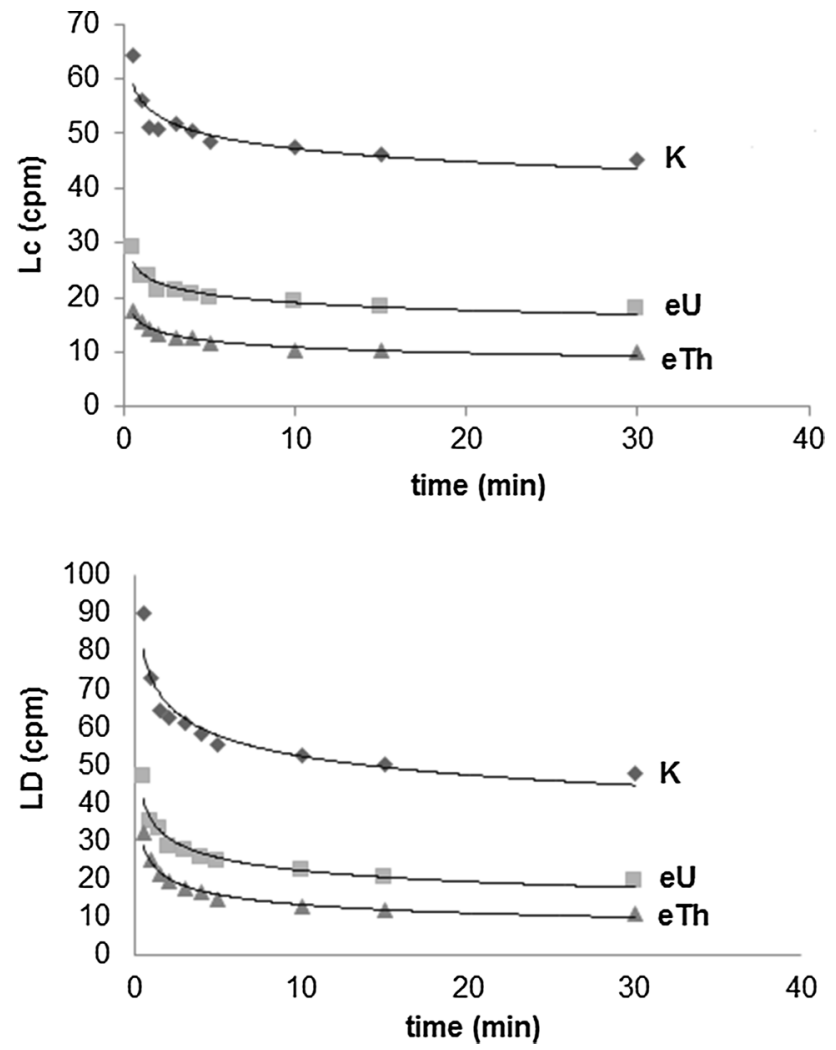

Fig. $2 L_{\mathrm{c}}$ and $L_{\mathrm{D}}$ values for $\mathrm{K}$, eU, and eTh plotted against the counting time (in min)

geometry and discrimination limit. They can be expressed in each window by $S_{\mathrm{K}}=\alpha_{\mathrm{K}, \mathrm{K}}, S_{\mathrm{U}}=\alpha_{\mathrm{U}, \mathrm{U}}$, and $S_{\mathrm{Th}}=\alpha_{\mathrm{Th}, \mathrm{Th}}$, allowing determine the concentrations of potassium $\left(C_{\mathrm{K}}\right)$, uranium $\left(C_{\mathrm{U}}\right)$, and thorium $\left(C_{\mathrm{Th}}\right)$ by $C_{\mathrm{K}}=(n \mathrm{~K})_{\text {net }} / S_{\mathrm{K}}$, $C_{\mathrm{U}}=(n \mathrm{U})_{\text {net }} / S_{\mathrm{U}}$, and $C_{\mathrm{Th}}=(n \mathrm{Th})_{\text {net }} / S_{\mathrm{Th}}$, where $(n \mathrm{~K})_{\text {net }}$, $(n \mathrm{U})_{\text {net }}$, and $(n \mathrm{Th})_{\text {net }}$ correspond to the net count rates in the $\mathrm{K}, \mathrm{eU}$, and eTh windows, respectively. Equations 7-9 express the $(n \mathrm{~K})_{\text {net }},(n \mathrm{U})_{\text {net }}$, and $(n \mathrm{Th})_{\text {net }}$ values taking into account the interference factors:

$(n \mathrm{Th})_{\mathrm{net}}=(n \mathrm{Th})-a(n \mathrm{U})_{\mathrm{net}}-b(n \mathrm{~K})_{\mathrm{net}}$

$(n \mathrm{U})_{\text {net }}=(n \mathrm{U})-\alpha(n \mathrm{Th})_{\text {net }}-g(n \mathrm{~K})_{\text {net }}$

$(n \mathrm{~K})_{\text {net }}=(n \mathrm{~K})-\gamma(n \mathrm{U})_{\text {net }}-\beta(n \mathrm{Th})_{\text {net }}$

The matricial Eqs. 10 and 11 allow determine the K, U, and $\mathrm{Th}$ concentrations from the net count rates in the $\mathrm{K}, \mathrm{eU}$, and eTh windows.

$\left[\begin{array}{c}C_{\mathrm{K}} \\ C_{\mathrm{U}} \\ C_{\mathrm{Th}}\end{array}\right]=\left[\begin{array}{ccc}\beta_{\mathrm{K}, \mathrm{K}} & \beta_{\mathrm{K}, \mathrm{U}} & \beta_{\mathrm{K}, \mathrm{Th}} \\ \beta_{\mathrm{U}, \mathrm{K}} & \beta_{\mathrm{U}, \mathrm{U}} & \beta_{\mathrm{U}, \mathrm{Th}} \\ \beta_{\mathrm{Th}, \mathrm{K}} & \beta_{\mathrm{Th}, \mathrm{U}} & \beta_{\mathrm{Th}, \mathrm{Th}}\end{array}\right]\left[\begin{array}{c}(n \mathrm{~K})_{\text {net }} \\ (n \mathrm{U})_{\text {net }} \\ (n \mathrm{Th})_{\text {net }}\end{array}\right]$
$\left[\begin{array}{ccc}\beta_{\mathrm{K}, \mathrm{K}} & \beta_{\mathrm{K}, \mathrm{U}} & \beta_{\mathrm{K}, \mathrm{Th}} \\ \beta_{\mathrm{U}, \mathrm{K}} & \beta_{\mathrm{U}, \mathrm{U}} & \beta_{\mathrm{U}, \mathrm{Th}} \\ \beta_{\mathrm{Th}, \mathrm{K}} & \beta_{\mathrm{Th}, \mathrm{U}} & \beta_{\mathrm{Th}, \mathrm{Th}}\end{array}\right]=\left[\begin{array}{ccc}\alpha_{\mathrm{K}, \mathrm{K}} & \alpha_{\mathrm{K}, \mathrm{U}} & \alpha_{\mathrm{K}, \mathrm{Th}} \\ \alpha_{\mathrm{U}, \mathrm{K}} & \alpha_{\mathrm{U}, \mathrm{U}} & \alpha_{\mathrm{U}, \mathrm{Th}} \\ \alpha_{\mathrm{Th}, \mathrm{K}} & \alpha_{\mathrm{Th}, \mathrm{U}} & \alpha_{\mathrm{Th}, \mathrm{Th}}\end{array}\right]^{-1}$

In general, $\alpha_{\mathrm{Th}, \mathrm{K}}, \alpha_{\mathrm{U}, \mathrm{K}}, \beta_{\mathrm{U}, \mathrm{K}}$, and $\beta_{\mathrm{Th}, \mathrm{K}}$ are null and other stripping factors are sometimes low, like $a$. In this paper, the large number of readings (380) for the standards permitted uses the net count rates for estimating the following stripping factors: $\alpha=0.8848 \pm 0.0273, \beta=0.8558 \pm 0.0291$, $\gamma=1.1314 \pm 0.0009, a=0.0338 \pm 0.0084$, $S_{\mathrm{K}}=1.5320 \pm 0.1146, S_{\mathrm{U}}=0.1021 \pm 0.0006$, and $S_{\mathrm{Th}}=0.0261 \pm 0.0001$.

The same database, stripping factors, and Eqs. 7-11 allowed generate Eqs. 12-14 for estimating concentration values from the count rate readings, which are useful in geochemical prospecting of mineral deposits (for instance, eU values above $100 \mathrm{ppm}$ may indicate areas enriched in uranium, perhaps of economic interest).

$$
\begin{aligned}
& C_{\mathrm{K}}=\left(0.6527 \pm 9.65 \times 10^{-16}\right) \\
& (n \mathrm{~K})_{\text {net }}-\left(0.7418 \pm 1.10 \times 10^{-15}\right)(n \mathrm{U})_{\text {net }} \\
& \quad+\left(0.0977 \pm 3.68 \times 10^{-16}\right)(n \mathrm{Th})_{\text {net }} \\
& C_{\mathrm{U}}=\left(1.0092 \pm 2.28 \times 10^{-16}\right) \\
& \quad(n \mathrm{U})_{\text {net }}-\left(8.9293 \pm 8.92 \times 10^{-16}\right)(n \mathrm{Th})_{\text {net }} \\
& C_{\mathrm{Th}}=-\left(1.3329 \pm 5.07 \times 10^{-16}\right) \\
& \quad(n \mathrm{U})_{\text {net }}+\left(39.4867 \pm 1.99 \times 10^{-15}\right)(n \mathrm{Th})_{\text {net }}
\end{aligned}
$$

Table 6 shows the counting rates in the $\mathrm{K}$, eU, and eTh windows for each standard, as well the estimated concentration values from the developed equations with their respective statistical residues (unexplicable variation).

\section{Exposure rate and dose rate calibrations}

The radioelements concentration allows evaluating their activity concentration from the corresponding specific activities, i.e., $2.589 \times 10^{5} \mathrm{~Bq} / \mathrm{g}$ for ${ }^{40} \mathrm{~K}, 1.246 \times 10^{4} \mathrm{~Bq} / \mathrm{g}$ for ${ }^{238} \mathrm{U}$, and $4.066 \times 10^{3} \mathrm{~Bq} / \mathrm{g}$ for ${ }^{232} \mathrm{Th}$ (IAEA 2008). The air exposure rate $\left(X_{\text {air }}\right)$ associated with the gamma activity from a radioactive source may be estimated by $X_{\text {air }}=\Gamma A^{2} / d^{2}$, where $A$ is the activity (in $\mathrm{Ci}$ ), $d$ is the source-measuring point distance (in $\mathrm{m}$ ), and $\Gamma$ is the exposure rate constant (in $\mathrm{R} \mathrm{m}^{2} / \mathrm{h} \mathrm{Ci}$ ) (Tauhata et al. 2013). Typical $\Gamma$ values are 0.779 , 7.48 , and $15.2 \mathrm{R} \mathrm{cm}^{2} / \mathrm{h} \mathrm{mCi}$ for ${ }^{40} \mathrm{~K},{ }^{214} \mathrm{Bi}\left({ }^{238} \mathrm{U}\right)$, and ${ }^{208} \mathrm{Tl}$ $\left({ }^{232} \mathrm{Th}\right.$ ), respectively (Tauhata et al. 2013). The parameter 
Table 6 Net count rate for each standard in the K, eU, and eTh windows and respective estimated values of the K, U, and Th concentration

\begin{tabular}{|c|c|c|c|c|}
\hline Standard & $(n \mathrm{~K})_{\text {net }}(\mathrm{cpm})$ & $\mathrm{K}(\%)$ & K (\%) estimated & Residue \\
\hline K6 & $0.9371 \pm 1.5741$ & 0 & $1.2922 \pm 0.3456$ & 1.2922 \\
\hline K5 & $0.3672 \pm 1.6545$ & 0.5 & $0.8352 \pm 0.2906$ & -0.1648 \\
\hline K4 & $1.1816 \pm 2.0438$ & 2.5 & $0.7297 \pm 0.5576$ & -2.2703 \\
\hline K3 & $7.7089 \pm 2.1867$ & 5 & $8.2579 \pm 0.7446$ & 3.2579 \\
\hline K2 & $36.7834 \pm 2.0023$ & 25 & $35.5733 \pm 0.7061$ & 10.5733 \\
\hline K1 & $80.6069 \pm 2.6660$ & 52 & $81.2906 \pm 1.0191$ & 29.2906 \\
\hline U5 & $-0.0727 \pm 1.7374$ & 0 & $-2.0032 \pm 0.3639$ & -2.0032 \\
\hline U4 & $14.1559 \pm 1.8138$ & 0 & $3.9979 \pm 0.3004$ & 3.9979 \\
\hline U3 & $73.3601 \pm 2.5186$ & 0 & $3.5824 \pm 0.5313$ & 3.5824 \\
\hline U2 & $138.9254 \pm 3.2160$ & 0 & $-6.0207 \pm 0.0670$ & -6.0207 \\
\hline U1 & $1160.7233 \pm 8.0024$ & 0 & $5.5029 \pm-0.1362$ & 5.5029 \\
\hline Th8 & $0.1240 \pm 2.1192$ & 0 & $-1.8190 \pm 0.5027$ & -1.8190 \\
\hline Th7 & $0.4156 \pm 1.8945$ & 0 & $-0.8935 \pm 0.4487$ & -0.8935 \\
\hline Th6 & $2.5310 \pm 1.8473$ & 0 & $3.3367 \pm 0.4781$ & 3.3367 \\
\hline Th5 & $-0.1059 \pm 1.7812$ & 0 & $-1.5934 \pm 0.4045$ & -1.5934 \\
\hline Th4 & $2.7312 \pm 2.0482$ & 0 & $-0.9387 \pm 0.4672$ & -0.9387 \\
\hline Th3 & $13.6939 \pm 2.0148$ & 0 & $-0.5541 \pm 0.2473$ & -0.5541 \\
\hline Th2 & $27.2897 \pm 1.9172$ & 0 & $-1.1007 \pm 0.1189$ & -1.1007 \\
\hline Th1 & $276.1431 \pm 4.1547$ & 0 & $0.3504 \pm 0.4781$ & 0.3504 \\
\hline Standard & $(n \mathrm{U})_{\text {net }}(\mathrm{cpm})$ & $\mathrm{U}(\mathrm{ppm})$ & eU (ppm) estimated & Residue \\
\hline K6 & $-0.2517 \pm 1.0290$ & 0 & $-6.8653 \pm-6.8653$ & -6.8653 \\
\hline K5 & $-0.2294 \pm 1.1756$ & 0 & $-15.1309 \pm-15.1309$ & -15.1309 \\
\hline K4 & $0.5071 \pm 1.1409$ & 0 & $-2.3735 \pm-2.3735$ & -2.3735 \\
\hline K3 & $-0.5193 \pm 1.0488$ & 0 & $-2.8738 \pm-2.8738$ & -2.8738 \\
\hline K2 & $0.8943 \pm 0.9184$ & 0 & $21.2216 \pm 21.2216$ & 21.2216 \\
\hline K1 & $-0.4444 \pm 1.0885$ & 0 & $-15.6184 \pm-15.6184$ & -15.6184 \\
\hline U5 & $1.6967 \pm 1.1279$ & 10.2 & $18.3911 \pm 18.3911$ & 8.1911 \\
\hline $\mathrm{U} 4$ & $8.9195 \pm 1.3227$ & 98.8 & $94.1238 \pm 94.1238$ & -4.6762 \\
\hline U3 & $61.7096 \pm 1.6204$ & 499 & $620.4086 \pm 620.4086$ & 121.4086 \\
\hline $\mathrm{U} 2$ & $128.5043 \pm 2.8712$ & 1025 & $1269.8436 \pm 1269.8436$ & 244.8436 \\
\hline $\mathrm{U} 1$ & $1025.5498 \pm 7.4522$ & 10070 & $10039.0994 \pm 10039.0994$ & -30.9006 \\
\hline Th8 & $1.7953 \pm 1.2765$ & 0 & $12.6991 \pm 12.6991$ & 12.6991 \\
\hline Th7 & $1.2506 \pm 1.1714$ & 0 & $6.1158 \pm 6.1158$ & 6.1158 \\
\hline Th6 & $-0.6631 \pm 1.0804$ & 0 & $-10.1026 \pm-10.1026$ & -10.1026 \\
\hline Th5 & $1.3627 \pm 1.1374$ & 0.4 & $10.4180 \pm 10.4180$ & 10.0180 \\
\hline Th4 & $3.7431 \pm 1.2686$ & 4 & $3.0212 \pm 3.0212$ & -0.9788 \\
\hline Th3 & $14.3912 \pm 1.5825$ & 20 & $20.1411 \pm 20.1411$ & 0.1411 \\
\hline Th2 & $28.9712 \pm 1.6965$ & 40 & $22.3727 \pm 22.3727$ & -17.6273 \\
\hline Th1 & $278.3644 \pm 3.4990$ & 400 & $401.7557 \pm 401.7557$ & 1.7557 \\
\hline Standard & $(n \mathrm{Th})_{\text {net }}(\mathrm{cpm})$ & Th (ppm) & eTh (ppm) estimated & Residue \\
\hline K6 & $0.4844 \pm 0.8331$ & 0 & $19.4623 \pm 31.5241$ & 19.4623 \\
\hline K5 & $1.4352 \pm 0.8470$ & 0 & $56.9774 \pm 31.8772$ & 56.9774 \\
\hline K4 & $0.8389 \pm 0.7149$ & 0 & $32.4501 \pm 26.7065$ & 32.4501 \\
\hline K3 & $-0.2651 \pm 0.9756$ & 0 & $-9.7754 \pm 37.1270$ & -9.7754 \\
\hline K2 & $-1.3658 \pm 0.8223$ & 0 & $-55.1227 \pm 31.2475$ & -55.1227 \\
\hline K1 & $1.2469 \pm 0.8831$ & 0 & $49.8270 \pm 33.4214$ & 49.8270 \\
\hline U5 & $-0.1532 \pm 0.6812$ & 0 & $-8.2988 \pm 25.3948$ & -8.2988 \\
\hline U4 & $-0.4597 \pm 0.9993$ & 0 & $-30.0387 \pm 37.6970$ & -30.0387 \\
\hline
\end{tabular}


Table 6 (continued)

\begin{tabular}{lrlrr}
\hline Standard & $(n \text { Th })_{\text {net }}(\mathrm{cpm})$ & Th $(\mathrm{ppm})$ & eTh $(\mathrm{ppm})$ estimated & Residue \\
\hline U3 & $0.2677 \pm 0.9145$ & 0 & $-71.6812 \pm 33.9496$ & -71.6812 \\
U2 & $3.0320 \pm 0.9998$ & 0 & $-51.5535 \pm 35.6501$ & -51.5535 \\
U1 & $34.8476 \pm 1.7231$ & 0 & $9.1031 \pm 58.1079$ & 9.1031 \\
Th8 & $0.6069 \pm 0.6786$ & 1.25 & $21.5723 \pm 25.0927$ & 20.3223 \\
Th7 & $0.7286 \pm 0.8290$ & 2.5 & $27.1018 \pm 31.1729$ & 24.6018 \\
Th6 & $0.3819 \pm 0.7547$ & 5 & $15.9656 \pm 28.3611$ & 10.9611 \\
Th5 & $0.3735 \pm 0.8756$ & 10.4 & $12.9304 \pm 33.0579$ & 2.5304 \\
Th4 & $3.8924 \pm 0.7297$ & 105.2 & $148.7072 \pm 27.1233$ & 43.5072 \\
Th3 & $14.0102 \pm 1.0857$ & 515 & $534.0347 \pm 40.7620$ & $1155.5733 \pm 48.6397$ \\
Th2 & $30.2429 \pm 1.2891$ & 1028 & $10275.8413 \pm 141.5149$ & -0347 \\
Th1 & $269.6317 \pm 3.7020$ & 10290 & & 127.5733 \\
\hline
\end{tabular}

$X_{\text {air }}$ allows calculating the air absorbed dose $\left(D_{\text {air }}\right)$ according to the relationship $D_{\text {air }}=0.869 \times X_{\text {air }}$, where the constant 0.869 corresponds to the mean energy necessary for producing an ions pair in air per electron charge (Tauhata et al. 2013). In this paper, $X_{\text {air }}$ and $D_{\text {air }}$ have been estimated from the net count rates in the $\mathrm{K}$, eU, and $\mathrm{T}$ Th windows according to the equations:

$$
\begin{aligned}
X_{\text {air }} & =(0.0248 \pm 0.00722)(n \mathrm{~K})_{\text {net }} \\
& +(0.0738 \pm 0.00823)(n \mathrm{U})_{\text {net }} \\
& +(0.0097 \pm 0.00277)(n \mathrm{Th})_{\text {net }} \\
D_{\text {air }} & =(0.2395 \pm 0.0697)(n \mathrm{~K})_{\text {net }} \\
& +(0.7120 \pm 0.0795)(n \mathrm{U})_{\text {net }} \\
& +(0.0925 \pm 0.0268)(n \mathrm{Th})_{\text {net }}
\end{aligned}
$$

The air exposure rate may be used to provide the exposure rate in another medium, for instance, water or tissue by adopting an appropriate conversion factor $(f)$. For water, some typical $f$ values vary from $0.881 \mathrm{rad} / \mathrm{R}(20 \mathrm{keV})$ to $0.964 \mathrm{rad} / \mathrm{R}$ (150 keV) (Tauhata et al. 2013). In this paper, $X_{\text {tissue }}$ has been calculated from the net count rate in the $\mathrm{K}$, $\mathrm{eU}$, and eTh windows, according to the equation:

$$
\begin{aligned}
X_{\text {tissue }} & =(0.0276 \pm 0.00802)(n \mathrm{~K})_{\text {net }} \\
& +(0.0819 \pm 0.00914)(n \mathrm{U})_{\text {net }} \\
& +(0.0106 \pm 0.00308)(n \mathrm{Th})_{\text {net }}
\end{aligned}
$$

Finally, the effective dose (Ed, in mSv/year) may be estimated from the net count rate in the $\mathrm{K}$, eU, and eTh windows by Ed $=\Gamma_{\mathrm{K}}(n \mathrm{~K})_{\text {net }}+\Gamma_{\mathrm{U}}(n \mathrm{U})_{\text {net }}+\Gamma_{\mathrm{Th}}(n \mathrm{Th})_{\text {net }}$ (Tauhata et al. 2013), whose empirical equation adopted in this paper is:

$$
\begin{aligned}
\mathrm{Ed} & =(0.0016 \pm 0.000452)(n \mathrm{~K})_{\text {net }} \\
& +(0.0046 \pm 0.000515)(n \mathrm{U})_{\text {net }} \\
& +(0.0006 \pm 0.000174)(n \mathrm{Th})_{\text {net }}
\end{aligned}
$$

Table 7 reports the values calculated for $X_{\text {air }}, D_{\text {air }}, X_{\text {tissue }}$, and Ed from the counting rates given in Table 6, illustrating the applicability of the database for environmental approaches.

\section{Effective dose in environments for Geology teaching}

The described procedures allowed perform $\gamma$-rays measurements in different environments related to activities developed for undergraduate and graduate Geology teaching at UNESP-São Paulo State University, IGCE-Geosciences and Exacts Sciences Institute, Rio Claro, São Paulo State, Brazil. The investigated sites were: LIT1-rocks deposit (litoteca) from DPM-Petrology and Metallogeny Department; MUS-"Heinz Ebert" Minerals and Rocks Museum; TEA-office of one professor responsible by the Mineralogy discipline located at DPM; LIT2-litoteca from UNESPetro (Geosciences Center Applied to Petroleum); CTD-courtyard of UNESPetro.

The net count rates (in cpm) in $\mathrm{K}$, eU, and eTh windows obtained in those sites are reported in Table 8, which were integrated and converted to effective dose (Ed, $\mathrm{mSv} / \mathrm{year})$ on using Eq. 18. Then, the values were modeled in Surfer software (Golden Software) by the kriging method through the spherical semivariogram model. Figures 3, 4, 5, 6, and 7 show the isolines geostatistical models generated for the Ed values calculated in the selected points. Some crystalline rocks (possibly enriched in natural radioelements) are stored in points P3, P4, and P5 at TEA site, justifying the enhanced Ed levels shown in Fig. 3. The elevated Ed value in P1 measuring point at LIT1 site (Fig. 4) is due to a highly radioactive rock sample stored in a rectangular lead shield in order to minimize the $\gamma$-rays emissions. The inferred mineralogical composition of this sample is thorianite $\left(\mathrm{ThO}_{2}\right)$, thorite $\left(\mathrm{ThSiO}_{2}\right)$, uranothorite $\left[(\mathrm{Th}, \mathrm{U}) \mathrm{SiO}_{4}\right]$, or uranothorianite [(Th, $\left.\mathrm{U}_{2} \mathrm{O}_{2}\right]$ (Bonotto 1996). This is reinforced by the high counting rate in the eTh window $\left({ }^{208} \mathrm{Tl}\right)$, 
Table 7 Estimated values of the air exposure rate $\left(X_{\text {air }}\right)$, air absorbed dose $\left(D_{\text {air }}\right)$, tissue exposure rate $\left(X_{\text {tissue }}\right)$, and effective dose (Ed) from the net count rate in the $\mathrm{K}$, eU, and $\mathrm{eTh}$ windows

\begin{tabular}{lrrrr}
\hline Standard & \multicolumn{1}{c}{$X_{\text {air }}(\mu \mathrm{R} / \mathrm{h})$} & \multicolumn{1}{c}{$D_{\text {air }}(\mathrm{nSv} / \mathrm{h})$} & \multicolumn{1}{c}{ Ed $(\mathrm{mSv} / \mathrm{year})$} \\
\hline K6 & $0.0950 \pm 0.2635$ & $0.9157 \pm 2.5402$ & $0.1054 \pm 0.2923$ & $0.0080 \pm 0.0223$ \\
$\mathrm{~K} 5$ & $0.2600 \pm 0.2781$ & $2.5046 \pm 2.6812$ & $0.2882 \pm 0.3085$ & $0.0219 \pm 0.0235$ \\
$\mathrm{~K} 4$ & $0.2192 \pm 0.2603$ & $2.1129 \pm 2.5105$ & $0.2431 \pm 0.2889$ & $0.0185 \pm 0.0220$ \\
K3 & $0.1089 \pm 0.3394$ & $0.0980 \pm 0.3059$ & $0.1089 \pm 0.3394$ & $0.0083 \pm 0.0258$ \\
K2 & $0.6817 \pm 0.2640$ & $6.5830 \pm 2.5454$ & $0.7575 \pm 0.2929$ & $0.0577 \pm 0.0223$ \\
K1 & $2.1169 \pm 0.3028$ & $20.4259 \pm 2.9200$ & $2.3505 \pm 0.3360$ & $0.1789 \pm 0.0256$ \\
U5 & $0.0862 \pm 0.2459$ & $0.8323 \pm 2.3712$ & $0.0958 \pm 0.2729$ & $0.0073 \pm 0.0208$ \\
U4 & $0.8666 \pm 0.3204$ & $8.3645 \pm 3.0889$ & $0.9625 \pm 0.3555$ & $0.0733 \pm 0.0271$ \\
U3 & $6.0528 \pm 0.3419$ & $58.4149 \pm 3.2967$ & $6.7221 \pm 0.3794$ & $0.5117 \pm 0.0289$ \\
U2 & $12.7360 \pm 0.4607$ & $122.9061 \pm 4.4428$ & $14.1434 \pm 0.5113$ & $1.0767 \pm 0.0389$ \\
U1 & $104.8596 \pm 1.0252$ & $1011.8939 \pm 9.8893$ & $116.4435 \pm 1.1380$ & $8.8642 \pm 0.0866$ \\
Th8 & $0.2398 \pm 0.2647$ & $2.3126 \pm 2.5530$ & $0.2661 \pm 0.2938$ & $0.0203 \pm 0.0224$ \\
Th7 & $0.2318 \pm 0.2801$ & $2.2347 \pm 2.7012$ & $0.2572 \pm 0.3108$ & $0.0196 \pm 0.0237$ \\
Th6 & $0.0855 \pm 0.2589$ & $0.8235 \pm 2.4966$ & $0.0948 \pm 0.2873$ & $0.0072 \pm 0.0219$ \\
Th5 & $0.1610 \pm 0.2838$ & $1.5531 \pm 2.7361$ & $0.1787 \pm 0.3149$ & $0.0136 \pm 0.0240$ \\
Th4 & $1.0476 \pm 0.2720$ & $10.0987 \pm 2.6232$ & $1.1621 \pm 0.3019$ & $0.0885 \pm 0.0230$ \\
Th3 & $3.9258 \pm 0.3591$ & $37.8471 \pm 3.4629$ & $4.3552 \pm 0.3985$ & $0.3315 \pm 0.0303$ \\
Th2 & $8.2762 \pm 0.4025$ & $79.7842 \pm 3.8811$ & $9.1812 \pm 0.4466$ & $0.6989 \pm 0.0340$ \\
Th1 & $75.9504 \pm 1.0291$ & $732.2042 \pm 9.9212$ & $84.2582 \pm 1.1417$ & $6.4141 \pm 0.0869$ \\
\hline
\end{tabular}

suggesting significant presence of gamma emissions from ${ }^{232}$ Th-descendants. The enhanced Ed value in P7 measuring point at MUS site (Fig. 5) is linked to the presence of an enriched U-ore. Some carbonate rocks slightly enriched in uranium and thorium in point P2 at LIT2 site justify the higher Ed values shown in Fig. 6, whereas the more elevated Ed levels in P1 at CTD site (Fig. 7) are possibly related to its proximity to the shelf for storing the radioactive standards used in our experiments.

All Ed values are below the guideline reference value of $20 \mathrm{mSv} / y e a r$ as recommended by International Commission on Radiological Protection (ICRP 2005) for the average of 5 years directed to occupationally exposed individuals. However, two values are higher than the guidance level of $1 \mathrm{mSv} /$ year for members of the public as proposed by ICRP (2005) and adopted by CNEN-National Commission on Nuclear Energy, Brazil (CNEN 2006). They were found in monitoring points located at sites LIT1 and MUS that are only occasionally utilized by professors and undergraduate and graduate students, thus, not implying on significant health risk for people. LIT1 is primarily used to store and catch samples of rocks, ores, and minerals, whereas MUS is only sometimes accessed for short duration visitation. In LIT1 site, the highest Ed value was found at P1 monitoring point after positioning the $\mathrm{NaI}(\mathrm{Tl})$ detector frontally over the lead box lid. In other monitoring points, the $\gamma$-rays readings were realized in air at $0.75-1.8 \mathrm{~m}$ above ground surface. In MUS site, the high Ed value was measured at P7 monitoring point.

Another independent radiological monitoring was done in P1 at LIT1 site (Fig. 4) using a Ludlum Model 193-6 Survey
Wand employing a 6" $\times 1$ " EJ212 Plastic Gamma Scintillator, whose calibration certificate 12-1510 was issued by METROBRAS (Center for Trials and Researches in Metrology) in June 21, 2012 (Borges et al. 2012). This instrument recorded the following air exposure rate data $\left(X_{\text {air }}\right.$, in $\left.\mu \mathrm{R} / \mathrm{h}\right)$ : (a) in the sides and top (closed box) - from 30 to $40 \mu \mathrm{R} / \mathrm{h}$; (b) in the top, close to the edge (open box) $-630 \mu \mathrm{R} / \mathrm{h}$. The highest Ed value recorded in this paper at $\mathrm{P} 1$ corresponded to $\sim 6 \mathrm{mSv} /$ year (Fig. 4) that is equivalent to $68 \mu \mathrm{R} / \mathrm{h}$. It is a value compatible with those reported by Borges et al. (2012) as the detectors efficiencies are different in both cases (the $\mathrm{NaI}(\mathrm{Tl})$ detector used in this paper exhibits better detection efficiency than the plastic gamma scintillator as reported by Saint-Gobain 2016).

Finally, an additional merit of the analytical protocol described in this paper consists on the possibility of converting activity concentration values in doses, which is, in general, a very difficult task due to the several parameters involved (see, for instance, the comments of PSE-Physics Stack Exchange; PSE 2017).

\section{Conclusions}

The $\chi^{2}$ test for the counting rates data of the $\gamma$-rays $\mathrm{NaI}(\mathrm{Tl})$ scintillation detector for different times $(1800,900,600,300$, $240,180,120,90,60$, and $30 \mathrm{~s}$ ) permitted to determine the optimum counting time for gamma rays readings of the standards used. The ideal counting time for in situ $\gamma$-rays determination should be done considering the contribution of the 
Table 8 Net count rate in the K, $\mathrm{eU}$, and eTh windows for $\gamma$-rays readings realized in air at 0.75 $1.8 \mathrm{~m}$ above ground surface at different environments from IGCE-UNESP-Rio Claro campus

\begin{tabular}{|c|c|c|c|c|c|c|}
\hline ID & $X(\mathrm{~m})$ & $Y(\mathrm{~m})$ & $t(\min )$ & $K(\mathrm{cpm})$ & $\mathrm{eU}(\mathrm{cpm})$ & eTh (cpm) \\
\hline \multicolumn{7}{|l|}{ MUS } \\
\hline $\mathrm{P} 1$ & 0.25 & 3.07 & 30.29 & 136.96 & 28.92 & 23.05 \\
\hline $\mathrm{P} 2$ & 0.25 & 6.69 & 30.43 & 144.54 & 34.57 & 26.12 \\
\hline $\mathrm{P} 3$ & 2.84 & 7.02 & 30.90 & 133.06 & 34.08 & 28.61 \\
\hline $\mathrm{P} 4$ & 6.87 & 7.02 & 30.58 & 198.33 & 85.38 & 29.79 \\
\hline P5 & 10.85 & 7.02 & 30.46 & 176.58 & 60.99 & 69.50 \\
\hline P6 & 10.85 & 6.07 & 48.98 & 169.25 & 54.29 & 42.91 \\
\hline P7 & 6.87 & 6.07 & 36.82 & 258.58 & 150.68 & 38.57 \\
\hline P8 & 2.84 & 6.07 & 30.41 & 135.57 & 33.83 & 28.44 \\
\hline P9 & 2.84 & 3.72 & 54.94 & 137.19 & 28.21 & 22.92 \\
\hline P10 & 6.87 & 3.72 & 30.53 & 133.70 & 35.54 & 22.60 \\
\hline P11 & 10.85 & 3.72 & 30.68 & 130.55 & 30.71 & 25.49 \\
\hline P12 & 10.85 & 2.76 & 30.52 & 126.01 & 29.91 & 23.10 \\
\hline P13 & 6.87 & 2.76 & 30.76 & 124.99 & 27.70 & 21.88 \\
\hline P14 & 2.84 & 2.76 & 30.30 & 127.48 & 30.37 & 22.38 \\
\hline P15 & 2.01 & 6.55 & 30.75 & 136.66 & 32.52 & 24.94 \\
\hline P16 & 3.69 & 6.55 & 30.50 & 144.32 & 35.81 & 28.66 \\
\hline P17 & 6.05 & 6.55 & 30.61 & 198.77 & 88.01 & 27.67 \\
\hline P18 & 7.72 & 6.55 & 30.69 & 163.06 & 60.48 & 28.35 \\
\hline P19 & 10.01 & 6.55 & 30.37 & 183.27 & 67.61 & 71.10 \\
\hline P20 & 12.86 & 8.13 & 30.84 & 166.47 & 41.73 & 38.85 \\
\hline $\mathrm{P} 21$ & 11.70 & 3.25 & 69.56 & 182.35 & 36.79 & 39.74 \\
\hline P22 & 10.01 & 3.25 & 30.51 & 128.55 & 30.81 & 22.03 \\
\hline P23 & 7.72 & 3.25 & 30.60 & 130.07 & 29.58 & 22.71 \\
\hline P24 & 6.05 & 3.25 & 30.19 & 130.96 & 29.81 & 19.18 \\
\hline P25 & 3.69 & 3.25 & 30.31 & 135.05 & 31.02 & 22.77 \\
\hline P26 & 2.84 & 0.42 & 30.17 & 121.10 & 27.61 & 20.75 \\
\hline P27 & 2.84 & 9.43 & 30.41 & 115.60 & 31.67 & 22.86 \\
\hline P28 & 10.85 & 9.43 & 29.95 & 127.05 & 33.39 & 27.75 \\
\hline P29 & 10.47 & 0.42 & 31.02 & 116.23 & 28.14 & 24.75 \\
\hline P30 & 6.87 & 0.42 & 33.99 & 118.55 & 27.06 & 21.74 \\
\hline P31 & 6.87 & 9.43 & 30.68 & 129.29 & 43.35 & 24.12 \\
\hline \multicolumn{7}{|l|}{ CTD } \\
\hline $\mathrm{P} 1$ & 38.99 & 1.72 & 28.37 & 93.90 & 23.97 & 17.48 \\
\hline $\mathrm{P} 2$ & 4.82 & 4.22 & 30.15 & 61.20 & 16.48 & 12.01 \\
\hline P3 & 10.42 & 19.56 & 30.44 & 58.14 & 18.03 & 15.01 \\
\hline $\mathrm{P} 4$ & 38.99 & 18.76 & 30.30 & 65.41 & 20.69 & 14.95 \\
\hline \multicolumn{7}{|l|}{ TEA } \\
\hline $\mathrm{P} 1$ & 0.32 & 1.47 & 36.23 & 120.41 & 27.65 & 21.33 \\
\hline $\mathrm{P} 2$ & 3.08 & 3.79 & 30.10 & 114.86 & 27.18 & 21.43 \\
\hline P3 & 1.02 & 4.46 & 30.23 & 145.30 & 39.03 & 24.87 \\
\hline P4 & 2.47 & 0.93 & 30.99 & 124.55 & 36.53 & 28.98 \\
\hline P5 & 1.65 & 4.46 & 30.96 & 137.55 & 30.23 & 24.09 \\
\hline \multicolumn{7}{|l|}{ LIT2 } \\
\hline $\mathrm{P} 1$ & 12.49 & 1.67 & 30.44 & 97.81 & 22.64 & 16.39 \\
\hline $\mathrm{P} 2$ & 6.52 & 4.80 & 30.38 & 99.29 & 27.16 & 19.85 \\
\hline P3 & 23.56 & 2.18 & 30.60 & 66.86 & 19.90 & 11.60 \\
\hline P4 & 22.27 & 4.56 & 30.47 & 77.27 & 20.84 & 13.13 \\
\hline P5 & 25.89 & 3.71 & 31.12 & 80.01 & 20.15 & 14.91 \\
\hline \multicolumn{7}{|l|}{ LIT1 } \\
\hline P1 & 9.19 & 3.05 & 30.16 & 1358.58 & 905.99 & 850.07 \\
\hline
\end{tabular}


Table 8 (continued)

\begin{tabular}{lrrrrrc}
\hline ID & $X(\mathrm{~m})$ & $Y(\mathrm{~m})$ & $t(\mathrm{~min})$ & $K(\mathrm{cpm})$ & $\mathrm{eU}(\mathrm{cpm})$ & $\mathrm{eTh}(\mathrm{cpm})$ \\
\hline P2 & 16.23 & 3.05 & 30.66 & 134.33 & 27.07 & 19.96 \\
P3 & 16.23 & 1.08 & 30.64 & 133.44 & 32.35 & 21.81 \\
P4 & 16.23 & 4.96 & 30.74 & 114.04 & 24.33 & 20.88 \\
P5 & -3.07 & 5.57 & 69.69 & 112.92 & 27.08 & 18.84 \\
P6 & 2.05 & 3.05 & 30.74 & 164.60 & 37.64 & 33.67 \\
P7 & 2.05 & 1.08 & 30.44 & 135.61 & 46.88 & 35.71 \\
P8 & 2.05 & 4.96 & 31.36 & 125.35 & 29.85 & 23.82 \\
\hline
\end{tabular}

" $X$ " and " $Y$ " correspond, respectively, to horizontal and vertical distances in the sketch diagrams shown in Figs. 3, 4, 5, 6, and 7 for the surveyed areas

Fig. 3 Isolines map of the effective dose at TEA site

Fig. 4 Isolines map of the effective dose at LIT1 site
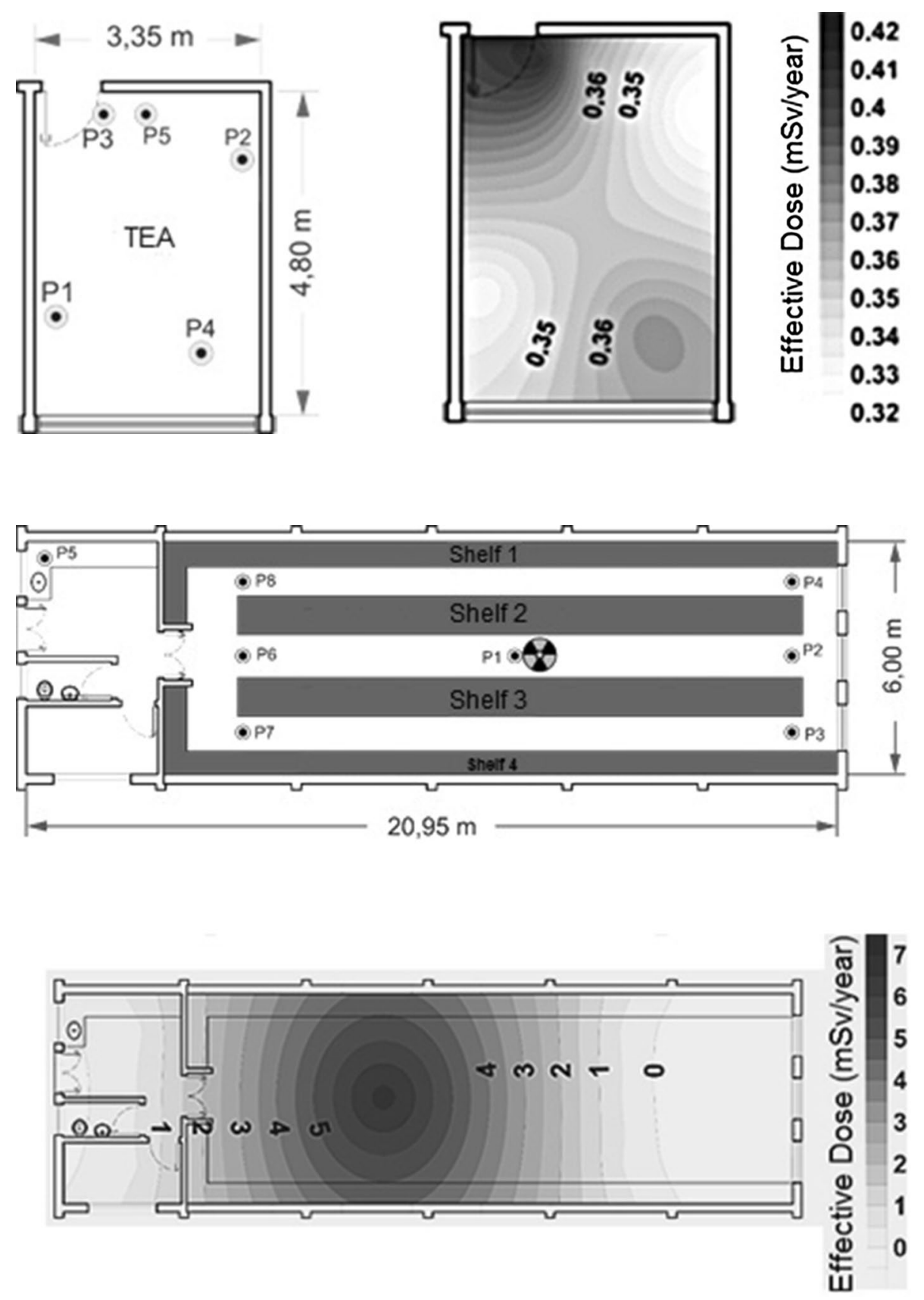

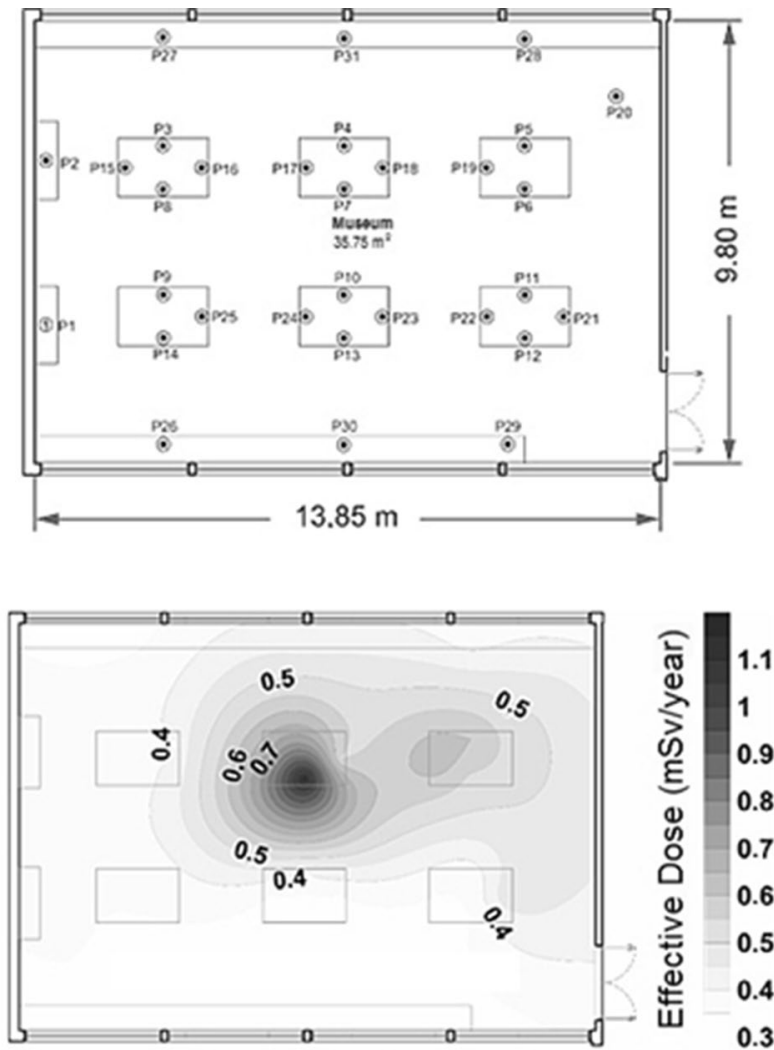

Fig. 5 Isolines map of the effective dose at MUS site
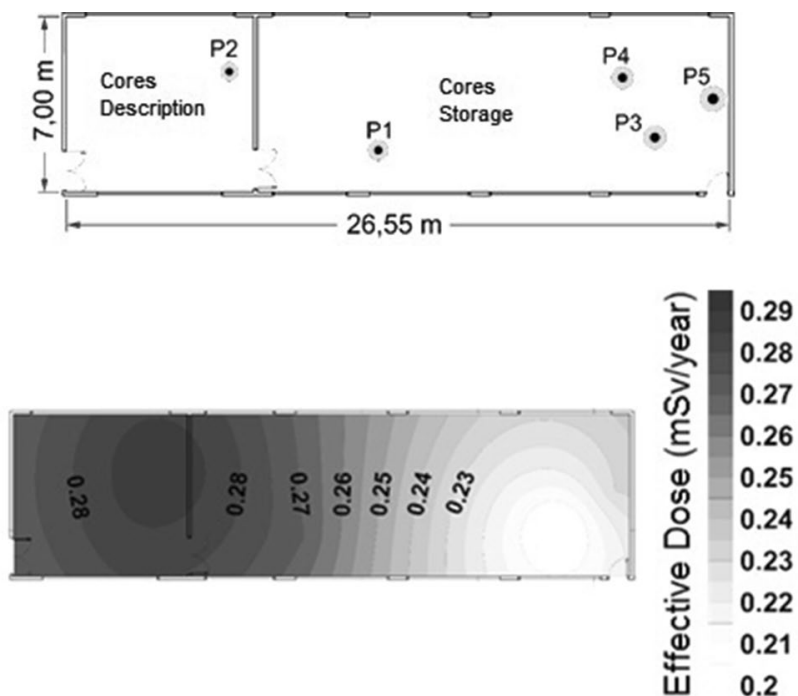

Fig. 6 Isolines map of the effective dose at LIT2 site

source (soil or rock) volume, mean density, and average radionuclide concentration in the materials. $\mathrm{K} 1, \mathrm{~K} 2, \mathrm{U} 1, \mathrm{U} 2, \mathrm{U} 3$, Th1,Th2, and Th3 standards used during the calibration steps provided values above the detection limit for each counting
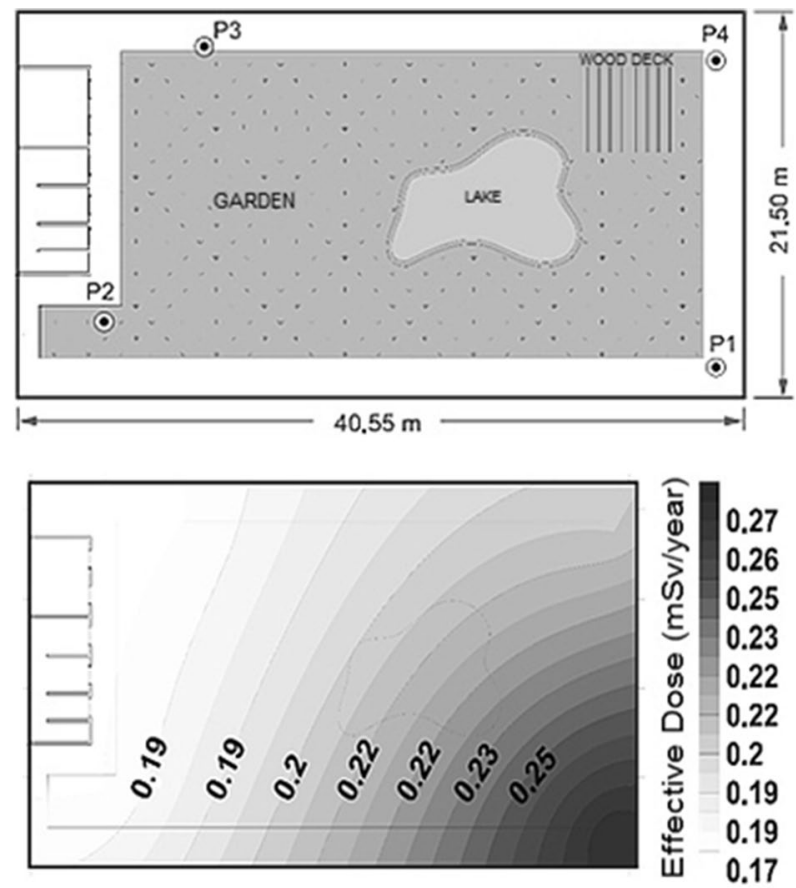

Fig. 7 Isolines map of the effective dose at CTD site

time adopted. In other cases, the count rates didn't exceed the background values, within the uncertainty levels adopted in this paper. Possible reasons could be the lack of a lead shield wall at the detector's frontal window and/or detector directed to $\sim 1 \mathrm{~m}$ distant ground surface from its positioning over a bench. Despite these limitations, the empirical calibration equations yielded satisfactory results as described along this paper. Geostatistical modeling allowed the data integration for calculating the effective dose (Ed) associated with sites related to activities developed for Geology teaching. Although some levels were above the guideline reference value of $1 \mathrm{mSv} /$ year, none intervention is required as the sites are primarily used to store/ display geological materials and only occasionally accessible for members of the public during short duration visits. The highest calculated Ed levels were much lower than the limiting value of $20 \mathrm{mSv} / \mathrm{year}$ for occupationally exposed individuals.

Acknowledgements CAPES (Coordination for the Development of Graduate People), Brasília (DF), Brazil, is greatly thanked by the Ms. Scholarship to EQB. UNESPetro, IGCE-UNESP-Rio Claro campus is also thanked for access to the analytical infrastructure. Two anonymous referees are greatly thanked for very helpful comments that improved the readability of this manuscript.

\section{References}

Acton QA (2013) Radioactive elements-advances in research and application. ScholarlyEditions, Atlanta 
Adams JAS, Freyer GE (1964) Portable ray spectrometer for field determination of thorium, uranium and potassium. In: Adams JAS, Lowder WM (eds) The natural radiation environment. University of Chicago Press, Chicago, pp 577-596

Adams JA, Gasparini P (1970) Gamma ray spectrometry of rocks. Elsevier, Amsterdam

Bevington PR (1969) Data reduction and error analysis for the physical sciences. McGraw-Hill Inc, New York

Bonotto DM (1996) Hydrogeochemical behaviour of ${ }^{222} \mathrm{Rn}$ and uranium isotopes ${ }^{234} \mathrm{U}$ and ${ }^{238} \mathrm{U}$ under controlled laboratory conditions and in natural systems. Post Ph.D. Thesis, UNESP-São Paulo State University, Rio Claro

Borges JC, Paula TC, Pires MA (2012) Radiometric survey reportLitoteca building. METROBRAS (Center for Trials and Researches in Metrology), Jardinópolis

Chu SYF, Ekström LP, Firestone RB (1999) The Lund/LBNL Nuclear Data Search. http://nucleardata.nuclear.lu.se/nucleardata/toi/index .asp. Accessed 01 Mar 2016

CNEN (National Commission of Nuclear Energy) (2006) Basic guidelines for radiological protection-Rule CNEN-NN-3.01. CNEN, Rio de Janeiro

Currie LA (1968) Limits for qualitative detection and quantitative determination. Anal Chem 40:586-593

Davis JC (1986) Statistics and data analysis in geology. Wiley, New York

Dickson BL, Scott KM (1997) Interpretation of aerial gamma ray surveys - adding the geochemical factors. AGSO J Aust Geol Geophys 17(2):187-200

Duval JS, Carson JM, Holman PB, Darnley AG (2005) Terrestrial radioactivity and gamma-ray exposure in the United States and Canada. U.S. Geological Survey Open-File Report 2005-1413

Grasty RL, Cox JR (1997) A car-borne gamma ray spectrometer system for natural radioactivity mapping and environmental monitoring. Report Nordic Nuclear Safety Research Secretariat, RESUME (Rapid Environmental Surveying Using Mobile Equipment) 95, pp 71-90

Grasty RL, Darnley AG (1971) Calibration of gamma-ray spectrometers for ground and airborne use. Geol Surv Can Pap 71-17:1-27

IAEA (International Atomic Energy Agency) (1989) Construction and use of calibration facilities for radiometric field equipment. Technical Report Series No. 309. IAEA, Vienna

IAEA (International Atomic Energy Agency) (1991) Airborne gammaray spectrometer surveying. Technical Report Series No. 323. IAEA, Vienna

IAEA (International Atomic Energy Agency) (2003) Guidelines for radioelement mapping using gamma ray spectrometry data. IAEATECDOC 1363. IAEA, Vienna

IAEA (International Atomic Energy Agency) (2008) Regulations for the safe transport of radioactive materials. TECDOC Series TS-G1.1 (Rev. 1). IAEA, Vienna
ICRP (International Commission on Radiological Protection) (2005) Low dose extrapolation of radiation related cancer risk. ICRP 99, vol 35, no. 4. Pergamon Press, Oxford

Ivanovich M, Harmon RS (1992) Uranium series disequilibrium: applications to environmental problems, 2nd edn. Clarendon Press, Oxford

Knoll GF (2010) Radiation detection and measurement, 4th edn. Wiley, Somerset

Kogan RM, Nazarov IM, Fridman SD (1971) Gamma spectrometry of natural environments and formations. IPST-Israel Programme for Scientific Translations, Jerusalem

L'Annunziata MF (2012) Handbook of radioactivity analysis, 3rd edn. Elsevier, Amsterdam

Leo WR (1994) Techniques for nuclear and particle physics experiments, 2nd edn. Springer, Heidelberg

L $\varphi$ vborg L, Mose E (1987) Counting statistics in radioelement assaying with a portable spectrometer. Geophysics 52(4):555-563

L $\varphi$ vborg L, Kirkegaard P, Christiansen EM (1976) Design of NaI(Tl) scintillation detectors for the use in gamma-ray surveys of geological sources. In: IAEA (International Atomic Energy Agency) (ed) Exploration for uranium ore deposits, proceedings series. IAEA, Vienna, pp 127-148

Perez-Andujar A, Pibida L (2004) Performance of CdTe, HPGe and $\mathrm{NaI}(\mathrm{Tl})$ detectors for radioactivity measurements. Appl Radiat Isot 60:41-47

PSE (Physics Stack Exchange) (2017) How to convert Bq/g to Sievert (Dose), and how to get values Sv/Bq? https://physics.stackexcha nge.com/questions/286399/how-to-convert-bq-g-to-sievert-doseand-how-to-get-values-sv-bq. Accessed 15 April 2017

Saint-Gobain (2016) Efficiency calculations for selected scintillators. Saint-Gobain Ceramics \& Plastics, Latrobe, p 13

Stoller BAC, Brady J, Flaum C, Melcher C, Vittachi A (1994) Saturation monitoring with the RST reservoir saturation tool. Oilfield Rev 6(1):29-39

Sudarshan M, Joseph J, Singh R (1992) Full energy peak efficiency of $\mathrm{NaI}(\mathrm{Tl})$ gamma detectors and its analytical and semi-empirical representations. J Phys D 25:1561-1567

Tauhata L, Salati I, Di Prinzio R, Di Prinzio AR (2013) Radioprotection and dosimetry: principles. IRD (Radioprotection and Dosimetry Institute), CNEN (National Commission of Nuclear Energy), Rio de Janeiro, p 345

Vuolo JH (1996) Errors theory principles, 2nd edn. Edgard Blücher, São Paulo

Young HD (1962) Statistical treatment of experimental data. McGrawHill Inc., New York, p 172 